\title{
The Alien Tort Statute and Flomo v. Firestone Natural Rubber Company: The Key to Change in Global Child Labor Practices?
}

Jessica Bergman

Indiana University Maurer School of Law, jesbergman@gmail.com

Follow this and additional works at: https://www.repository.law.indiana.edu/ijgls

Part of the International Law Commons, Juvenile Law Commons, and the Labor and Employment Law Commons

\section{Recommended Citation}

Bergman, Jessica (2011) "The Alien Tort Statute and Flomo v. Firestone Natural Rubber Company: The Key to Change in Global Child Labor Practices?," Indiana Journal of Global Legal Studies: Vol. 18 : Iss. 1 , Article 18.

Available at: https://www.repository.law.indiana.edu/ijgls/vol18/iss1/18

This Note is brought to you for free and open access by the Law School Journals at Digital Repository @ Maurer Law. It has been accepted for inclusion in Indiana Journal of Global Legal Studies by an authorized editor of Digital Repository@Maurer Law. For more information, please contactrvaughan@indiana.edu.

\section{$\Psi$}

JEROME HALL LAW LIBRARY

INDIANA UNIVERSITY

Maurer School of Law
Bloomington 


\title{
The Alien Tort Statute and Flomo $v$. Firestone Natural Rubber Company: The Key to Change in Global Child Labor Practices?
}

\author{
JESSICA BERGMAN ${ }^{\star}$
}

\begin{abstract}
The case of Flomo v. Firestone Natural Rubber Company involves child laborers' claims that labor practices on a Liberian rubber plantation violate international norms. Though the case was recently resolved in favor of the defendants at the district court level, the case's complicated procedural and substantive history offers insight into the viability of future child labor claims. This Note examines the Flomo case and explores how standards from the ATS and the United States Supreme Court case Sosa v. Alvarez-Machain apply to future plaintiffs' claims. This Note also analyzes the potential repercussions that plaintiffs face in using the ATS as a tool to influence global child labor practices and highlights the realities of ATS child labor litigation.
\end{abstract}

\section{INTRODUCTION}

There are 218 million child laborers in the world, and many of them face exploitative conditions that place their welfare at risk. ${ }^{1}$ With trade

* Executive Symposium Editor, Indiana Journal of Global Legal Studies; J.D. Candidate, 2011, Indiana University Maurer School of Law; B.A., 2008, University of Kansas. I would like to thank Alfred Aman, Jr., Michael Grossberg, and Christiana Ochoa, Professors of Law, Indiana University Maurer School of Law, for their guidance and comments on prior drafts of this Note.

1. Numbers are based on the International Labour Organization's (ILO) most recent global estimate of child laborers ages five to seventeen around the world. "[T] he highest proportion of child laborers (69\%) work in the agriculture sector, followed by the services sector (22\%) and the industrial sector $(9 \%)$. In agriculture, children work in subsistence farming, small- to mediumsized family farms, and large-scale commercial plantations. No matter the size of the farm, children working in agriculture often face a myriad of health and safety risks. They commonly perform physically demanding tasks under harsh environmental conditions, often for long hours with little rest. Some children working in agriculture are required to apply or are exposed to pesticides and herbicides without adequate protective gear." U.S. DEP'T OF LAB. BUREAU OF INT'L

Indiana Journal of Global Legal Studies Vol. 18 \#1 (Winter 2011)

(C) Indiana University Maurer School of Law 
becoming more liberalized, corporations are racing to produce goods quicker and cheaper than their competitors, which has exacerbated human rights problems for workers in developing countries. ${ }^{2}$ Because developing countries are often unwilling or unable to implement child labor laws within their borders, employers of children must be regulated by outside entities for any recognized international norms to be effectuated. 3 The United States, as a global power, is currently in a position to recognize internationally recognized standards of conduct regarding labor. ${ }^{4}$ Recent judicial developments regarding the Alien Tort Statute (ATS) ${ }^{5}$ - a U.S. jurisdictional statute-allow private parties to bring suit against U.S. corporations that engage in some of the "worst forms of child labor"6 abroad. Because a court can examine U.S. interests and tailor a remedy accordingly, the ATS alleviates many of the issues that prevent Congress from allowing causes of action under

LAB. AFF., U.S. DEPARTMENT OF LABOR'S 2008 FTNDINGS ON THE WORST FORMS OF CHILD LABOR, at xxii (2008) (citing Int'l Lab. Org. recent estimates) (footnote omitted), available at http://www.dol.gov/ilab/programs/ocft/PDF/20080CFTreport.pdf. See generally Federico Blanco Allais \& Frank Hagemann, Child labour and education: Evidence from SIMPOC surveys, (Int'1 Lab. Org., Working Paper, June 2008) (discussing the effect of child labor on education), available at $\mathrm{http}: / / \mathrm{www}$.ilo.org/ipecinfo/product/viewProduct.do?productId $=8390$.

2. Grace C. Spencer, Her Body is a Battlefield: The Applicability of the Alien Tort Statute to Corporate Human Rights Abuses in Juarez, Mexico, 40 GoNZ. L. REv. 503, 50304 (2004) (discussing the effects that "compassionate capitalism" has on female workers' human rights in Juarez, Mexico).

3. What constitutes an international norm, at least for the purposes of a court allowing a private claim for a violation of such norm to proceed in a U.S. federal court, is determined by whether a particular violation has reached the status of customary law. See generally Sosa v. Alvarez-Machain, 542 U.S. 692, 733 (2004) (reversing the availability of remedies for the alien under FCTA and the ATS).

4. Justin D. Cummins, Invigorating Labor: A Human Rights Approach in the United States, 19 EMORY INT'L L. REV. 1, 3 (2005).

5. 28 U.S.C. $\$ 1350(2010)$.

6. The worst forms of labor are defined in the ILO Convention 182 as "(a) all forms of slavery or practices similar to slavery, such as the sale and trafficking of children, debt bondage and serfdom and forced or compulsory labour, including forced or compulsory recruitment of children for use in armed conflict; (b) the use, procuring or offering of a child for prostitution, for the production of pornography or for pornographic performances; (c) the use, procuring or offering of a child for illicit activities, in particular for the production and trafficking of drugs as defined in the relevant international treaties; (d) work which, by its nature or the circumstances in which it is carried out, is likely to harm the health, safety, or morals of children." International Labour Organization, Convention Concerning the Prohibition and Immediate Action for the Elimination of the Worst Forms of Child Labour, art. 3, adopted June 17, 1999, 38 I.L.M. 1207 [hereinafter Convention on Worst Forms of Child Labour]. The Convention is utilized for definitional purposes in this paper because it is "the key source of international child labor standards" for the purposes of Roe v. Bridgestone Corp., 492 F. Supp. 2d 988, 1021 (S.D. Ind. 2007), the case which allowed the child laborers' claims to proceed in the district court and the subject of this paper. 
child labor treaties. ${ }^{7}$ United States corporations are changing their child labor policies in reaction to cases involving the ATS.

One such case is Flomo $v$. Firestone Natural Rubber Company, 8 which was recently decided in favor of the defendants in the U.S. District Court for the Southern District of Indiana. ${ }^{9}$ The plaintiffs in the

7. Congress has not yet ratified a treaty that would create a cause of action by child laborers. Thus, any cause of action must be judicially created, if children are to be able to seek redress against corporations operating abroad. The ATS allows courts to hear child laborers' claims that a violation of an international norm has occurred. See generally Anna A. Kornikova, Note, International Child Labor Regulation 101: What Corporations Need to Know About Treaties Pertaining to Working Youth, 34 BRooK. J. INT'L L. 207, 219-24 (2008) (discussing the existing international treaties that pertain to child labor and how none create a cause of action).

8. Flomo v. Firestone Natural Rubber Co., No. 06-cv-00627 (S.D. Ind. Oct. 5, 2010). The caption has changed during the litigation. After summary judgment was granted in favor of all of the remaining defendants with the exception of Firestone Natural Rubber Company, the case became Flomo v. Firestone Natural Rubber Company. Entry Following Oral Argument at 1, Flomo, No. 06-cv-00627 (No. 585); see also Notice of Caption Change at 1, Flomo, No. 06-cv-00627 (No. 203). The relationship of the parties originally included in the complaint is complex. Bridgestone Corporation wholly-owns Firestone Natural Rubber Company as a subsidiary. Firestone Natural Rubber Company owns BFS Diversified Products, LLC as a subsidiary. Firestone National Rubber Company, LLC (FSNR) is a "division" of BFS Diversified Products, LLC. Firestone Liberia, previously the Firestone Plantation Company, is a Liberian subsidiary of FSNR. 492 F. Supp. 2d at 992. According to plaintiffs, FSNR "owns, controls, and directs Firestone's Liberia plantation." Plaintiffs' Response in Opposition to Defendants' Briefs in Support of Motion for Summary Judgment on Plaintiffs' Claims for Punitive Damages (Dkt. 495-1) and Plaintiffs' Secondary Liability Theories (Dkt. 496-1) at 1, Flomo, No. 06-cv-00627 (No. 530) [hereinafter Plaintiffs' Opposition to Defendants' Summary Judgment Motion on Punitive Damages]. The plaintiffs originally sued Firestone Liberia under the name of the Firestone Plantation Company, but Firestone Plantation Company was dismissed from the suit because it was not served. Order on Motion to Dismiss Unserved Defendants at 1, Flomo, No. 06-cv-00627 (No. 69). In a recent response to defendant's summary judgment motion, plaintiffs limited their theory of liability to FSNR as the entity directly legally responsible for plaintiffs' claims and the court granted summary judgment in favor of all other defendants, dismissing them from the litigation. FSNR was the sole defendant remaining in the final stages. Entry Following Oral Argument at 1, Flomo, No. 06-cv00627 (No. 585); Plaintiff's' Response in Opposition to Defendants' Briefs in Support of Motion for Summary Judgment on Plaintiffs' Claims for Punitive Damages (Dkt. 495-1) and Plaintiffs' Secondary Liability Theories (Dkt. 496-1), supra, at 2 n.3.

9. Flomo v. Firestone Natural Rubber Co., No. 06-cv-00627 (S.D. Ind. Oct. 5, 2010) (issuing summary judgment in favor of defendant because no corporate liability exists under the ATS and relying heavily on Kiobel v. Royal Dutch Petroleum Co., Nos. 06-4800cv, 06-4876-cv, 2010 U.S. App. LEXIS 19382 (2d Cir. Sept. 17, 2010)). See generally Gregory T. Euteneier, Comment, Towards a Corporate "Law of Nations": Multinational Enterprises' Contributions to Customary International Law, 82 TUL. L. REV. 757 (2007) (discussing mechanisms by which multinational corporations could be held civilly liable under the ATS for a violation of an international norm); Chimène I. Keitner, Conceptualizing Complicity in Alien Tort Cases, 60 Hastings L.J. 61 (2008) (exploring the different circuits' approaches to corporate liability in cases under the ATS. 
case, a group of Liberian children, alleged that they were forced to perform hazardous labor-in violation of international norms-on the defendant's rubber plantation. 10 The court originally held that it had subject matter jurisdiction over the plaintiffs' claims pursuant to the ATS 11 and allowed them to go forward. ${ }^{12}$ Flomo is the first case in which a plaintiff's claims have survived the ATS jurisdictional bar and the pleading stage. As a result, the case offers many useful procedural and substantive lessons for litigating future child labor claims. ${ }^{13}$ This paper adds to the debate regarding the ATS by examining the Flomo case indepth and exploring the various obstacles that future plaintiffs will encounter in bringing similar suits. ${ }^{14}$

Though globalization is frequently viewed from a top-down perspective, this paper examines globalization from the bottom-up, specifically how domestic law and private action can influence global markets and institutions. ${ }^{15}$ While past international regulatory mechanisms have failed to effectively regulate child labor, in part due to the difficulties in defining child labor, private parties may, be able to

10. Bridgestone Corp., 492 F. Supp. $2 \mathrm{~d}$ at 1019.

11. Alien Tort Statute, 28 U.S.C. $\$ 1350$ (2010). The litigation lasted almost five years; the initial complaint was filed on November 17, 2005. See Complaint, Flomo, No. 06-cv00627 (No. 2).

12. See Bridgestone Corp., 492 F. Supp. 2d at 1019-23 (denying defendant's motion for dismissal).

13. See Complaint, supra note 11 , at paras. 94-99. The court originally intended to define the types of child labor in this case when ruling on the parties' motions for summary judgment. Order at 3, Flomo, No. 06-cv-00627 (No. 569) (discussing original order that stated, in ruling on parties' summary judgment motion, the court "would define 'worst forms' of child labor in the context of this case"). That ruling never occurred as planned, and the litigation proceeded without clear definitional boundaries as to what child labor is in the context of this case. However, because the court originally stated in its opinion denying dismissal on plaintiffs' claims of forced child labor that the ILO is the "key source" of child labor standards for the purpose of this case, the ILO is primarily utilized in this paper. Bridgestone Corp., 492 F. Supp. $2 \mathrm{~d}$ at 1021.

14. It is important to recognize that this paper is not about enforcing an international norm against all forms of child labor, in large part, because it is far from clear that an international norm exists for a ban on all forms of child labor, even within the United States. See generally Bridgestone Corp., 492 F. Supp. 2d at 1021-22 (discussing the various forms of child labor allowed in the United States, such as on family farms, and the difficulties determining which prohibitions on child labor have reached the status of an international norm).

15. See Alfred C. Aman, Jr., Globalization from the Ground up: a Domestic Perspective, in THE IMPACT OF GLOBALIZATION ON THE UNITED STATES: LAW AND GOVERNANCE 2, 3-4 (Beverly Crawford ed., 2008) (describing the bottom-up perspective to globalization); see also SASKIA SASSEN, A Sociology of GLOBALIZATION 45-47 (Jeffrey C. Alexander ed., 2007) (describing scholarship on three basic positions on the state and globalization, and adding a fourth). 
effectively regulate child labor practices through the judicial process. ${ }^{16}$ This Note emphasizes that domestic actors, specifically courts and private parties such as those that were involved in the Flomo case, are impacting global practices. Specifically, in this case, fear of litigation from multiple suits-brought on behalf of child laborers seeking redress in a U.S. court for past harm - may cause corporations to slowly change their labor regulations. ${ }^{17}$ In fact, because of the repeated litigation of similar plaintiffs' claims, corporations are already aware of the potential for litigation under the ATS.

To show how private parties can use the ATS to influence global child labor practices, this Note examines the Flomo case and explores how standards from the ATS and a prior Supreme Court case, Sosa $v$. Alvarez-Machain, ${ }^{18}$ apply to future plaintiffs' claims. This Note also reviews the potential repercussions that plaintiffs may face in using the ATS as a regulatory tool and highlights the realities of ATS child labor litigation. Section I provides a brief overview of the ATS and the Supreme Court decision interpreting it. Section II discusses the need for a redress for child laborers in a globalized world and argues that the ATS may provide such redress. Section III examines the Flomo case, following the Supreme Court's recently articulated framework for ATS claims, 19 to determine which sources of law could be used to support an international child labor norm. Section III also reviews the practical and legal obstacles that plaintiffs faced in this case and provides risk management guidance for future litigants bringing similar claims.

16. See SASKla SASSEN, Territory, Authority, Rights: From MEdieval to Global ASSEMBLAGES 308-09 (2006) (arguing that it is possible to "engage the global from within the national and through national institutional channels"). But see Archon Fung, Dara O'Rourke, \& Charles Sabel, Realizing Labor Standards, in CAN WE PUT AN END TO SwEATShops? 3, 3.40 (Joshua Cohen \& Joel Rogers eds., 2001) (arguing one way to achieve effective labor regulation is through transnational organizations such as the ILO, the United Nations, or the World Bank, but also cautioning that any effective strategy must consider a country's individual economic circumstances).

17. This change exemplifies the bottom-up approach, in which the state is not just influenced by globalization but the state also influences the globalization process. See generally Alfred C. Aman, Jr., The Globalizing State: A Future-Oriented Perspective on the Public/Private Distinction, Federalism and Democracy, 31 VAND. J. Transnat'L L. 769, 773 (1998).

18. Sosa v. Alvarez-Machain, 542 U.S. 692 (2004) (interpreting the ATS and articulating the standard for determining when a private cause of action should be recognized under federal common law for violations of the law of nations).

19. Id. at 731-35. 


\section{THE SOSA V. ALVAREZ-MaChaIN FRAMEWORK FOR ClaIMS UNDER THE ALIEN TORT STATUTE}

Pursuant to the ATS, federal courts have "original jurisdiction of any civil action by an alien for a tort only, committed in violation of the law of nations or a treaty of the United States." 20 The Act, however, does not create a cause of action. It only gives the federal courts subjectmatter jurisdiction over a "relatively modest set of actions alleging violations of the law of nations" that are recognized at common law. ${ }^{21}$ In the landmark decision Sosa v. Alvarez-Machain, the Supreme Court articulated the standard for determining whether to recognize a private claim under federal common law for violations of international legal norms. ${ }^{22}$ Though the Court stated it was leaving the judicial door ajar to allow private claims, it noted that the door was "subject to vigilant doorkeeping, and thus open to a narrow class of international norms." 23

In Sosa, the plaintiff, a Mexican national, sued the United States, various U.S. federal agents, and a Mexican collaborator, alleging that he was unlawfully abducted from Mexico, taken to the United States, and arrested.24 Citing the ATS, the plaintiff sought damages against defendants, including the United States, and argued that the arrest had taken place in violation of the law of nations. ${ }^{25}$ The district court awarded summary judgment in favor of the plaintiff, and the U.S. Court of Appeals for the Ninth Circuit affirmed, finding (1) that the ATS created a cause of action for an alleged violation of the law of nations, and (2) that there was a clear and universally recognized norm prohibiting such an arrest. ${ }^{26}$ However, the Supreme Court reversed the Ninth Circuit's decision and held that the ATS was a jurisdictional

20. 28 U.S.C. $\$ 1350$ (2010). The history of the ATS has been written about in detail before and will not be discussed in this article; rather, more attention will be given to the framework for determining whether a court can recognize a private claim for a violation of an international norm under the ATS. See Sosa, 542 U.S. at $712-721$ (providing a concise history of the ATS); Jeremy K. Schrag, Comment, The Tenth Circuit's Misconstruction of Statutory Rape in International Law Under the Alien Tort Claims Act of 1789, 47 WASHBURN L.J. 817, 821-24 (2008); Beth Stephens, Judicial Deference and the Unreasonable Views of the Bush Administration, 33 BROOK. J. INT'L L. 773-80, 776 (2008).

21. Sosa, 542 U.S. at 720 .

22. Id. at 731-33.

23. Id. at 729 .

24. Id. at 698 .

25. Id. at 698 .

26. Id. at 698-99. The original case was brought in 1993, after Alvarez-Machain received a judgment of acquittal on the charges surrounding his arrest. The procedural history of the case is lengthy and convoluted and demonstrates the difficulties that the courts have in effectively dealing with claims asserted under the ATS. Id. 
statute and did not provide a cause of action. ${ }^{27}$ Rather, federal common law provided the cause of action which would allow a plaintiff to sue in U.S. federal court for a violation of a modest number of international law norms, and the allegedly unlawful arrest did not fall within that modest number. ${ }^{28}$

In determining what constitutes a violation against the law of nations for the purposes of jurisdiction under the ATS, the Sosa Court approved the use of sources found in Article 38(1) of the International Court of Justice (ICJ) statute as evidence of international norms. Article 38(1) examines whether there is a treaty, international norm, or custom that would provide a cause of action. ${ }^{29}$ The Court also found that the norm needed to be as definite and as accepted among civilized nations as international law violations with a potential for personal liability that were in existence at the time the ATS was originally enacted in 1789.30 Although reversing the Ninth Circuit, the Supreme Court approvingly cited several cases from the Ninth Circuit that created a framework for ATS determinations. The Ninth Circuit's standard required a norm to be "universal, specific, and obligatory." 31

As a warning to lower courts to carefully limit private claims under federal common law, the Sosa majority urged judges to consider the practical consequences of a private cause of action in U.S. courts under the ATS. ${ }^{32}$ After implementing the framework set out in the opinion, the Sosa Court ultimately rejected the plaintiff's arguments, finding his arrest violated "no norm of customary international law so well defined as to support the creation of a federal remedy." ${ }_{3}$ However, the Sosa

27. Id. at 724 .

28. Id. at 724,738 .

29. Evidence of an international norm is determined by looking at international agreements, international custom, the practices of civilized states, and judicial opinions and commentaries. Id. at 733-34 (citing The Paquete Habana, 175 U.S. 677, 700 (1900)).

30. At the time the ATS was passed by the First Congress, it is likely that only three violations had risen to the status of international law: "violations of safe conducts, infringements of the rights of ambassadors, and piracy." Sosa, 549 U.S. at 724.

31. Id. at 732; see Pauline Abadie, A New Story of David and Goliath: The Alien Tort Claims Act Gives Victims of Environmental Injustice in the Developing World a Viable Claim Against Multinational Corporations, 34 GoLDEN GATE U. L. REV. 745, 763-65 (2004) (discussing the variety of standards that can be used to determine if an international norm exists).

32. These practical considerations include the following: "whether international law extends the scope of liability for a violation of a given [international] norm to the perpetrator being sued, if the defendant is a private actor such as a corporation or individual," whether all of the remedies have been exhausted in the domestic legal system, and whether the court should exercise deference as to other political branches. Sosa, 549 U.S. at $732 \mathrm{nn} .20,21$.

33. Id. at 738 . 
opinion does not foreclose future ATS litigation. Rather, it indicates that evidence of an international norm sufficient for recognizing private claims under the ATS regarding a human rights violation must meet certain standards, potentially foreclosing certain claims from ever being successfully litigated. ${ }^{34}$

\section{The ATS as a TOOL For Change IN ChILD Labor PRACTICES}

Like many U.S. companies, Firestone Natural Rubber Company (FSNR), the main defendant in the Flomo litigation, is headquartered in the United States with its production facilities in developing countries. ${ }^{35}$ The global expansion of markets leads to many new cultural and economic relationships between such U.S. corporations, developing countries, and these countries' corporations, creating numerous jobs and benefits. ${ }^{36}$ However, unequal bargaining power between the businesses and the individuals with which they contract exacerbates existing human rights problems. ${ }^{37}$ The growth of the international marketplace has brought greater diversity and tolerance, but this economic growth often comes at the expense of the most vulnerable: children. ${ }^{38}$ Child workers' access to redress from corporations violating international norms has the potential to equalize power between workers and their employers. ${ }^{39}$ However, the United States has not yet ratified a treaty providing a cause of action to child laborers, so any redress in the United States would have to be found in the U.S. courts, rather than any international tribunal.

As stated in The Economist, "of all the alleged sins of globalization, child labour is among the most scorned." 40 While the rationales behind

34. Id. The court noted that the argument that the plaintiff's arrest was a violation of international law "expresses an aspiration that exceeds any binding customary rule having the specificity we require. Creating a private cause of action to further that aspiration would go beyond any residual common law discretion we think it appropriate to exercise." Id. (footnote omitted).

35. FSNR is the company against which the plaintiffs are seeking damages. Plaintiffs argue that FSNR is directly liable for Firestone Liberia's child labor practices. Plaintiffs' Opposition to Defendants' Summary Judgment Motion on Punitive Damages, supra note 8, at 2 n.2, 9 n.4; Bridgestone Corp., 492 F. Supp. $2 \mathrm{~d}$ at 992.

36. Jeffrey L. Dunoff, Does Globalization Advance Human Rights?, 25 BROOK. J. INT'L L. 125, 126-27 (1999) (describing a theory of globalization that developing nations derive social, economic, and political benefits from globalization).

37. Spencer, supra note 2 , at 504 .

38. Dr. Ranee Khooshie Lal Panjabi, Sacrificial Lambs of Globalization: Child Labor in the Twenty-First Century, 37 DENV. J. INT'L L. \& POL'Y, 421, 421 (2009).

39. See, e.g., Spencer, supra note 2 , at 506.

40. Panjabi, supra note 38, at 421 (Sickness or Symptom?, ECONOMIST, Feb. 5, 2004, at 73). 
protecting children transcend national borders, international regulation of child labor, as opposed to domestic regulation, must contend with the "developing world's concern for [its] own economic development."4l Thus, other domestic and international regulations have not failed because the reasons for prohibiting child labor exist only in the United States, but rather because regulating child labor in developing countries presents unique difficulties. These practices persist throughout the world due to differing conceptions of what constitutes child labor, partial failures of past agreements to have effective enforcement mechanisms, and specific obstacles to international regulation in general.

The United States has not yet created a cause of action for child laborers by way of treaty, in part because of differing conceptions of childhood. Congress has been reluctant to sign a treaty that is independently enforceable in U.S. courts due to uncertainty surrounding which definition of childhood will be used in litigation. ${ }^{42}$ However, the ATS allows the courts to examine international law subject to numerous restrictions, ensuring that U.S. interests, which include and require examining the various definitions of childhood, are considered in the analysis. ${ }^{43}$ Thus, the ATS is a unique remedy that follows general treaty standards and ensures that U.S. interests are preserved, which is not possible using a treaty by itself as the cause of action.

Child labor has been addressed on both international and domestic levels through agreements, treaties, and legislation. ${ }^{44}$ However, these measures differ drastically in how child labor is defined and regulated. ${ }^{45}$ These differences can be traced to the competing values and policies surrounding the conception of childhood, arising from a nation's social,

41. Michele D'Avolio, Child Labor and Cultural Relativism: From 19th Century America to 21st Century Nepal, 16 PACE INT'L L. REV. 109, 140 (2004).

42. See generally Anna Maria Gabrielidis, Human Rights Begin at Home: A Policy Analysis of Litigating International Human Rights in U.S. State Courts, 12 BUFF. HUM. RTS. L. REV. 139, 153-60 (2006) (explaining how to use treaties in litigation and the differences between self-executing clauses and non-self executing clauses).

43. See Sosa v. Alvarez-Machain, 542 U.S. 692, 732-33 (2004) (discussing the various policies that courts may consider deciding whether a cause of action exists under the ATS).

44. See generally Philip E. Veerman, The Rights of the Child and the Changing IMAGE OF CHILDHOOD (1992) (detailing the international conventions, declarations, treaties, and domestic states' legislation that have dealt with children's rights since 1918 and the ramifications they have on child labor).

45. See generally William E. Myers, The Right Rights? Child Labor in a Globalizing World, 575 ANNAIS AM. ACAD. POL. \& Soc. SCI. 38, 45-53 (2008) (summarizing three global reference points for national and international policy regarding child labor). 
cultural, and economic circumstances. ${ }^{46}$ Differing conceptions of the child can lead to different ideas about a child's ability to work, and can lead to different assessments of a child's competence and maturity. ${ }^{47}$ As a result, what constitutes child labor depends on the definition of childhood, which itself depends on who defines it. In the United States, only "oppressive" forms of child labor are illegal. ${ }^{48}$ For example, while a sixteen-year-old may not work in manufacturing or mining at anytime, ${ }^{49}$ a twelve-year-old may work on a farm outside of school hours with the consent of his or her parents. ${ }^{50}$ In Liberia, on the other hand, domestic statutory law provides that children under sixteen may be employed as long as their work does not interfere with their education. ${ }^{51}$ Despite the cultural, political, and economic obstacles that lead to such varied definitions of child labor, international child labor treaties have been drafted and subsequently ratified by a large part of the global community, including the United States. ${ }^{52}$

Numerous efforts to regulate child labor in the global marketplace have served as social mobilization tools articulating core labor standards, but these efforts have largely failed to enforce the standards they embody. ${ }^{53}$ The two most prominent child labor agreements of the International Labour Organization (ILO), the UN's specialized labor organization, are the Convention No. 138: Concerning the Minimum Age for Admission to Employment ${ }^{54}$ and Convention No. 182: Concerning the Prohibition and Immediate Action for the Elimination of the Worst Forms of Child Labour. ${ }^{55}$ Unfortunately, "some countries

46. Id. at 40-41 (discussing the policy tensions surrounding who gets to decide what constitutes child labor).

47. David ARchaRd, ChILDREN: RightS \& CHILDHOOD 15.41 (2004) (discussing the differing conceptions of childhood by different theorists through time).

48. 29 U.S.C. $\S 212$ (c) (2006).

49. See 29 U.S.C. $\S 203(1)$ (2006) (defining oppressive child labor).

50. See 29 U.S.C. $\$ 213(c)(1)(b)(2006)$.

51. See also 2007 Findings on the Worst Forms of Child Labor - Liberia, U.S. DEP'T OF LAB. (Aug. 27, 2008), available at http://www.unhcr.org/refworld/docid/48caa47c18.html (citing Labour Practices Law, Title 18 and 18A, sec. 74, 1506, para 11 (Liberia)).

52. See, e.g., Convention on Worst Forms of Child Labour, supra note 6 . This Convention was ratified by the United States on February 12, 1999. Convention No. C182, ILOLEX: DATABASE OF INT'L LABOUR STANDARDS, http://www.ilo.org/ilolex/cgi-lex/ratifce. pl?C182 (last visited Sept. 30, 2010).

53. Frederick B. Jonassen, A Baby-Step to Global Labor Reform: Corporate Codes of Conduct and the Child, 17 MINN. J. INT'L L. 7, 13 (2008).

54. International Labour Organization, Convention Concerning Minimum Age for Admission to Employment, adopted June 26, 1973, 1015 U.N.T.S. 297 [hereinafter Minimum Age Convention].

55. Convention on Worst Forms of Child Labour, supra note 6. 
where child labor is widespread have not signed Convention 138," 56 and the enforcement mechanism provided for in the Convention has only been used once, with little effect. ${ }^{57}$ Similarly, the U.N.'s Convention on the Rights of the Child lacks an enforcement mechanism entirely. 58 Agreements generated within the World Trade Organization (WTO) have been unable to include recognition of workers' rights, and side agreements under the North American Free Trade Agreement (NAFTA) have been limited in scope, requiring members to "enforce [only] their own labor laws," leading to much criticism. ${ }^{59}$ Though other mechanisms for regulating child labor have been repeatedly proposed in Congress, they too have failed in part due to conflict with the General Agreement on Tariffs and Trade (GATT), which calls for "no prohibition or restrictions" to be placed upon any contracting party by another. ${ }^{60}$

In addition to definitional problems and enforcement failures, there are specific obstacles to international regulation. First, implementing child labor standards may actually be worse for the children affected by these regulations. ${ }^{61}$ Like the United States in the early $20^{\text {th }}$ century, children often work to support their families. Children working in substandard conditions may forgo education or even sustenance if they are prohibited from working. Prohibitions on child labor may further reduce the overall household income when these children are depended upon for the aggregated survival of the family unit. Without that extra income, families may lose their means to survive. Children may also work to pay for their education. Thus, taking away their jobs may simultaneously take away their opportunity for any future advancements. ${ }^{62}$ Another pressing concern is that child labor regulation will not end child labor at all, but will instead force children to work in more harmful positions, such as being a child prostitute or a child

56. Jonassen, supra note 53, at 15 (citing Ratifications by Convention, ILOLEX: DATABASE OF INT'L LABOUR STANDARDS, http://www.ilo.org/ilolex/cgi-lex/ratifce.pl?c138 (last visited Sept. 25, 2010); Timothy A. Glut, Changing the Approach to Ending Child Labor: An International Solution to an International Problem, 28 VAND. J. INT'L L.1203, 1226 n.170 (1995)).

57. Id. at 15 (citing Sarosh C. Kuruvilla \& Anil Verma, International Labor Standards, Soft Regulation, and National Government Roles, 48 J. INDUS. REL. 41, 45 (2006)).

58. Id. at 16; United Nations Convention on the Rights of the Child art. 32, adopted Nov. 20, 1989, 1577 U.N.T.S. 3 [hereinafter Rights of the Child].

59. Jonassen, supra note 53, at 19 (citing Kuruvilla, supra note 57, at 47 (explaining the limits of the North American Agreement on Labor Cooperation (NAALC), a division of NAFTA)).

60. Id. at 20.21 (citing General Agreement on Tariffs and Trade art. XI, Oct. 30, 1947, 61 Stat. A3, 55 U.N.T.S. 187).

61. See, e.g., id. at 25-26.

62. Id. 
soldier with employers that are able to evade regulation. ${ }^{63}$

Second, protectionist policies may raise the cost of labor, depress labor demand and job prospects, and force workers to "crowd inferior job markets, depressing wages and working conditions." 64 Many argue that developed nations were able to reach industrialized status today because they were able to use child labor during a critical point in time. ${ }^{65}$ Child labor regulations would increase the price of exports and make developing countries less competitive in the global marketplace, potentially leading to a loss of employment for their citizens. ${ }^{66}$ Thus, prohibiting child labor in developing countries may further disadvantage them economically, leaving them unable to reach an equal standing with developed nations. 67

Lastly, there are problems with the very conception of children's rights. The right to be free from abusive labor exploitation is not like other rights, such as freedom of speech or worship. Rather, it is the right to be prohibited from working even if the child wants to work. ${ }^{68}$ Thus, a child's labor right is more of a type of "developmental right," implying limitations rather than freedom. ${ }^{69}$ Because this right silences children's voices by its very indifference, children must rely upon adults to advocate for their interests. ${ }^{70}$ Children's inability to advocate for themselves is one of the greatest obstacles to establishing children's rights. ${ }^{71}$

Many of these arguments raise legitimate reasons not to regulate child labor. However, at least one treaty, the ILO Convention for the Elimination of the Worst Forms of Child Labour, appears to be cognizant of developing countries' positions and balances their need to be competitive in the form of cheap labor in the global marketplace

63. See Harvard Law Review, Developments in the Law-Jobs and Borders: III. Legal Tools for Altering Labor Conditions Abroad, 118 HARV. L. REV. 2202, 2219 n.95 (2005) (citing William B. Gould IV, Labor Law for a Global Economy: The Uneasy Case for International Labor Standards, 80 Neb. L. Rev. 715, 741 (2001)).

64. Pranab Bardhan, Some Up, Some Down, in CAN WE PUT AN END to SwEatshops? 49, 50 (Joshua Cohen \& Joel Rogers eds., 2001) (arguing that regulation of labor standards should consider opportunity costs and side effects on the working poor).

65. Jonassen, supra note 53, at 27 n.146 (citing Timothy A. Glut, Changing the Approach to Ending Child Labor: An International Solution to an International Problem, 28 VAND. J. INT'L L. 1203, 1208 (1995)).

66. D'Avolio, supra note 41 , at 11 .

67. Id.

68. Jonassen, supra note 53 , at 29 .

69. Id. at 30 .

70. Id.; see Kornikova, supra note 7, at 225 (advocating involving the child in decisionmaking about his or her life in contrast to the traditional practice of the child remaining silent).

71. Jonassen, supra note 53, at 29; Kornikova supra note 7 , at 225-26. 
while eliminating the worst forms. ${ }^{72}$ Thus, the scope of the prohibition on child labor can be narrowed to only certain forms. For instance, it appears in Flomo that only forced and hazardous forms of child labor have reached the status of an international norm, so children can still labor, as long as they are not engaged in the "worst forms." ${ }^{3}$ Developing countries making anti-protectionist arguments are correct in finding that child labor is good for a nation's economy, but the good is only short-term. ${ }^{74}$ Ultimately, child labor will inhibit socio-economic growth, creating a cycle of poverty. Because children are paid less than adults, child labor ultimately displaces adult workers and depresses adult wages. ${ }^{75}$ The problems surrounding the regulation of child labor should not be pushed to the side, or no regulatory measure will ever be effective. However, at the same time, these problems should not prohibit individual nations, both developed and developing, from trying to find solutions that work for everyone, especially the children.

\section{FLOMO V. FIRESTONE NATURAL RUBBER COMPANY: BACKGROUND, LEGAL ISSUES, AND PRACTICAL REALITIES}

Flomo $v$. Firestone Natural Rubber Company was the first case in which a court examined and subsequently found that (1) allegations of forced and hazardous child labor were sufficient for subject matter jurisdiction under the ATS, and (2) the allegations, if true, were a violation of the law of nations. ${ }^{76}$ The plaintiffs' complaint alleged that the child laborers on Firestone Liberia's rubber plantation performed hazardous labor by "walk[ing] barefoot for up to an hour carrying 150 pounds of latex, balancing two heavy buckets on a stick" three times a day. ${ }^{77}$ This task led to "extreme scars and bone and muscle deformities on their shoulders."78 The complaint also alleged that many of the children developed diseases due to chemical exposure from their jobs applying pesticides and fertilizers. ${ }^{79}$ Lastly, the complaint alleged that the children performed forced labor under the theory that Firestone Liberia's production polices required children to work in order for the

72. Convention on Worst Forms of Child Labour, supra note 6.

73. Roe v. Bridgestone Corp., 492 F. Supp. 2d 988, 1021 (S.D. Ind. 2007).

74. Michael D'Avolio, supra note 41, at 26-27.

75. Id. at 116-18.

76. See Bridgestone Corp., 492 F. Supp. 2d at 1019-24 (denying defendant's motion for dismissal based on lack of subject-matter jurisdiction and failure to state a claim on which relief can be granted).

77. Complaint, supra note 11 , at para. 47.

78. Id.

79. Id. at paras. $4,47,65$. 
rubber tappers to meet their quotas. 80

Soon after the complaint was filed, the defendants filed a motion to dismiss based on lack of subject-matter jurisdiction and failure to state a claim upon which relief can be granted. ${ }^{81}$ The court denied the motion, finding that plaintiffs' claims of the worst forms of child labor stated a claim. for relief and could not be dismissed on the pleadings. ${ }^{82}$ When determining if an international norm existed for the purposes of the defendants' motion, the court examined all of the relevant sources of international law, as put forth in Sosa. ${ }^{83}$ The court used the Ninth Circuit's standard of "universal, specific, and obligatory" norms, but the opinion did not distinguish this language from the test articulated by the Supreme Court. ${ }^{84}$ The trial court briefly examined the practical implications of creating a cause of action under the jurisdictional grant of $\mathrm{ATS}^{85}$ in its supplemental opinion granting summary judgment in

80. Id. at paras. 4, 48,.For specifics of the individual types of hazardous work that the children performed and how it interfered with their school work, see Plaintiffs' Response in Opposition to Defendants' Brief and Supplemental Brief in Support of Motion for Judgment on the Pleadings or, in the Alternative, Motion for Summary Judgment at 2330, Flomo, No. 06-cv-00627 (No. 295) [hereinafter Plaintiffs' Opposition to Defendants' Motion for Judgment on Pleadings].

81. Bridgestone Corp., 492 F. Supp. $2 \mathrm{~d}$ at 992.

82. As mentioned before, the ATS is a jurisdictional statute: it does not provide a cause of action. Thus, the sufficiency of the claim is not relevant to whether the plaintiffs have established subject-matter jurisdiction. It should be sufficient that plaintiffs allege an arguable violation of the law of nations. "[T] he absence of a valid (as opposed to arguable) cause of action does not implicate subject-matter jurisdiction, i.e., the courts' statutory or constitutional power to hear the case." Bridgestone Corp., 492 F. Supp. 2d at 1006, 1022 (quoting Steel Co. v. Citizens for a Better Env't, 523 U.S. 83, 89 (1998)) (emphasis in original).

83. Bridgestone Corp., 492 F. Supp. 2d at 1008-09.

84. The Bridgestone court does not appear to take the meaning of "universal" literally, as some commentators have argued the standard may necessitate. Furthermore, the court treated "specific" and "definite" content the same and seemed not to differentiate between obligatory and "accepted among civilized nations" or the 18th century paradigm. Thus, at least in the Bridgestone case, the differences between the language used to describe the different frameworks seems to be insignificant. Id. at 1022-24.

85. The Supreme Court noted in Sosa that judges should proceed with great caution when deciding whether to create a new private cause of action under the ATS for violating international law, and should be wary of legislative and executive roles in managing foreign affairs. Creating remedies under the ATS can have adverse foreign policy consequences. Further, since there is no congressional mandate to create new causes of action under the ATS, the courts must be very careful in light of the fact that several times the United States Supreme Court has restricted the courts' powers in interpreting and applying international law. An example of such a restriction is when the Senate ratifies a treaty, yet ensures that it is not self-executing. Sosa, 542 U.S. at 727-31. Additionally, many problems arise in creating a cause of action for child laborers. If children cannot labor in "legitimate" areas, they may be pushed into prostitution or other illegal forms of labor in order to survive. See William B. Gould IV, Fundamental Rights at 
favor of the defendants. ${ }^{86}$

\section{A. The Flomo Court Correctly Found That an International Norm Exists as to Plaintiffs' Claims of Child Labor}

Although there are no treaties that create a cause of action for inhumane child labor practices, various international agreements taken together may evidence an international norm. To determine if an international norm exists, the court should first examine all of the current international agreements regarding the alleged violation that may show evidence of an international norm. ${ }^{87}$ Before examining the existing international agreements that focus on child labor, the Supreme Court's application of their own standards in Sosa must be analyzed for guidance on what evidence will satisfy the Sosa standards of "definite" and "accepted among civilized nations," standards which are required before an international norm can be recognized under federal common law. ${ }^{88}$ What is considered "definite" and "accepted" is never explicitly explained in the opinion, so care must be taken to determine how a court should deal with the specific agreements. Next, the application of the Sosa framework will be examined.

\section{The Supreme Court's Application of the Framework in Sosa}

In Sosa, the plaintiff cited two international agreements as evidence that an international norm against arbitrary arrest existed: the Universal Declaration of Human Rights (the Declaration) and the International Covenant on Civil and Political Rights (ICCPR), both of which the United States ratified.89 The Supreme Court found that although the cited agreements may have had moral authority, they had "little utility under the standard set out in this opinion."90 The "little utility" of these two documents, at least to the Court, arose from

Work and the Law of Nations: An American Lawyer's Perspective, 23 HoFSTRA LAB. \& EMP. L.J. 1, 40 (2005) (arguing that enforcing international child labor law will be difficult because of the need for child labor rights to be coupled with financial assistance to Third World countries to ensure that children do not move into the worst forms child labor); Kornikova, supra note 7, at 223-25 (discussing whether a child's right to survival should "trump" a child's right not to labor).

86. Flomo v. Firestone Natural Rubber Company, No. 06-cv-00627 at 15-18 (S.D. Ind. Oct. 19, 2010).

87. Sosa, U.S. 542 at $732-34$.

88. Id. at 732 .

89. Id. at 734 .

90. Id. 
deficiencies in the treaties' enforceability. ${ }^{91}$ First, "the Declaration 'does not of its own force impose obligations as a matter of international law."'92 Second, as the Court noted, while the ICCPR "does bind the United States as a matter of international law, the United States ratified [the ICCPR] on the express understanding that it was not selfexecuting and so did not itself create obligations enforceable in the federal courts."93 The plaintiff also noted "findings by a U.N. working group that [the plaintiff's] detention was arbitrary under the Declaration, [the ICCPR], and customary international law."94 However, the court found that the U.N.'s finding alone was not sufficient to raise a private cause of action and Congress, not the Court, was the appropriate place to make a request for compensation based on the working group's finding. ${ }^{95}$ The Court found that both the Declaration and ICCPR did not "themselves establish the relevant and applicable rule of international law." 96 This implied that the two treaties could be used as evidence of an international norm, but additional evidence was needed in order to prove a claim had reached the status of "binding customary international law."97

\section{Application of the Sosa Framework to International Child Labor Agreements}

Because international child labor agreements are often drafted in broad terms, a norm regarding child labor generally has not yet been reached. ${ }^{98}$ However, by applying the Sosa framework, the district court

91. Id. at 734-35.

92. Id.; Tai-Heng Cheng, The Universal Declaration of Human Rights at Sixty: Is It Still Right for the United States?, 41 CORNELL INT'L L.J. 251, 289 (2008) (quoting Sosa, 542 U.S. at 734) (discussing the basics of the Declaration, its role in international law, and nations' obligations under it).

93. Sosa, 542 U.S. at 735.

94. Id. at $738 \mathrm{n} .30$.

95. Id.

96. Id. at 735 (emphasis added).

97. Id. (explaining that, in order to discern whether a claim has reached the status of binding customary law in the absence of a treaty, the Court must resort to "the customs and usages of civilized nations; and as evidence of these, to the works of jurists and commentators" (citing The Paquete Habana, 175 U.S. 677, 700 (1900))).

98. See Melissa Torres, Labor Rights and the ATCA. Can the ILO's Fundamental Rights be Supported Through ATCA Litigation?, 37 ColUM. J.L. \& Soc. ProBs. 447, 46162 (2004) (discussing the problem of determining whether a prohibition on child labor covers all child labor or just exploitative forms). Some scholars argue that the idea of labor regulation originated not at the domestic level, but the international level. E.g., Christopher L. Erickson \& Daniel J.B. Mitchell, Labor Standards and Trade Agreements: U.S. Experience, 19 COMP. LAB. L. \& POL'Y J. 145, 147-48 (1998). Despite this early start at 
in Flomo found that an international norm existed in regard to forced and hazardous labor, ${ }^{99}$ in spite of no treaty imposing "of its own force ... obligations as a matter of international law." 100 In large part, this is due to the plaintiffs' successful strategy, thus far, of consistently arguing that, regardless of the enforceability of a treaty, a treaty is still evidence of an international norm. ${ }^{101}$ The district court found that the ILO Convention 182 was the most convincing agreement that showed evidence of a standard. However, many international agreements on child labor were used in the plaintiffs' summary judgment motions. ${ }^{102}$ These agreements will be discussed below.

\section{a. The Convention on the Rights of the Child}

Although dealing with a broad array of children's human rights issues, The Convention on the Rights of the Child (CRC) recognizes that children have the right "to be protected from economic exploitation and from performing any work that is likely to be hazardous, to interfere with the child's education, or to be harmful to the child's health or physical, mental, spiritual, moral or social development."103 The CRC also requires all parties to consider "the best interests of the child."104 The standard is worded so that it is only a primary consideration in the analysis, not the determining factor. ${ }^{105}$ Further, the inherent relative nature of the word "best" allows a nation to take into account their cultural, social, and economic views. ${ }^{106}$ Though Liberia has ratified the CRC, the United States has not, which may affect a court's ability to use the CRC as evidence that an international norm exists. ${ }^{107}$

the international level, the differences between nations' conceptions of child labor are still great.

99. Roe v. Bridgestone Corp., 492 F. Supp. 2d 988, 1022 (S.D. Ind. 2007).

100. Sosa, 542 U.S. at 734 .

101. See Plaintiffs' Opposition to Defendants' Motion for Judgment on Pleadings, supra note 80 , at $7-9$.

102. Bridgestone Corp., 492 F. Supp. 2d at 1021.

103. Rights of the Child, supra note 54.

104. Id. at art. 3.

105. Id.

106. Kornikova, supra note 7 , at $224-25$.

107. Database: Chapter VI, Human Rights, 11. Convention on the Rights of the Child, UNITED NATIONS TREATY COLLECTION, http://treaties.un.org/Pages/ViewDetails.aspx?src=TREATY\& mtdsg_no=IV-11\&chapter=4\&lang=en (last accessed Nov. 4, 2010). 


\section{b. The ILO Convention Concerning Minimum Age for Admission to Employment}

' The ILO's Minimum Age Convention 138 provided a new framework for analyzing child labor. The framework allowed for children to engage in certain work, depending on the stage of economic development of the country and age of the child. 108 Thus, the standard was variable, but it also included a recommendation that the minimum age for work that is likely to jeopardize the health, safety, or morals of young persons be set at eighteen and that light work may be allowed for a child as young as thirteen, as long as the work does not harm their education and social development. ${ }^{109}$ The convention's goal was to end all child labor, ${ }^{110}$ with flexibilities built into the agreement to allow developing countries leeway with their labor policies. ${ }^{111}$ Despite this apparent flexibility, many developed and developing countries were slow to ratify it, finding that the guidelines did not always complement their own laws. ${ }^{112}$ Because of the difficulties with an agreement that has specific guidelines for nations to follow, neither the United States nor Liberia has ratified the treaty. ${ }^{113}$ However, despite the lack of ratifications to the treaty, the plaintiffs in Flomo used the agreement as evidence of an international norm, stating that Convention 138 simply recognized an existing international consensus condemning child labor. ${ }^{114}$ The U.S. Department of State affirmed the plaintiffs' assertion, finding that, in reference to the Convention 138, "an international consensus exists, based on several key International Labor [sic] Organization (ILO) Conventions, that certain worker rights constitute core labor standards," which include freedom from forced and child labor. ${ }^{115}$

108. Minimum Age Convention, supra note 54, at art. 2-3.

109. Id. at arts. 2(4), 3(1). The ILO is made up of 174 countries and was established in 1919. It was the first specialized agency of the U.N. E.g., Michael J. Dennis, Current Development: The ILO Convention on the Worst Forms of Child Labor, 93 AM. J. INT'L L. 943, 948 n.1 (1999) (citing NEW ZEALAND MINISTRY OF FOREIGN AFFAIRS AND TRADE, UNITED NATIONS HANDBOOK 211-20 (1998)).

110. Minimum Age Convention, supra note 54, at pmbl., art. 10.

111. See ILO Minimum Age Recommendation (No. 146) art. 10(1), June 26, 1973, available at http://www.ilo.org/ilolex/cgi-lex/convde.pl?R146.

112. See Breen Creighton, Combating Child Labour: The Role of International Labour Standards, 18 COMP. LAB. L.J. 362, 386-92 (1997) (discussing the specific reasons why some countries chose not to ratify the convention).

113. ILOLEX Database of Int'l Labour Standards, Ratifications by Country or by Convention, supra note 52.

114. Plaintiffs' Opposition to Defendants' Motion for Judgment on Pleadings, supra note 80 , at 7 .

115. U.S. DEP'T OF STATE, 1997 HUMAN RIGHTS REPORT (1998), auailable at http://www.state.gov/www/global/human_rights/1997_hrp_report/overview.html. 
c. The ILO Convention Concerning the Prohibition and Immediate Action for the Elimination of the Worst Forms of Child Labor

The Flomo court found that The Worst Forms of Child Labor Convention 182 was the key source of international child labor standards.116 The 1999 agreement was created to eliminate the "unconditional worst forms of child labor" and "hazardous work" by children.117 By its very nature, the treaty draws lines between both the "worst" forms and other forms of labor for children. The Flomo court noted the importance of creating categories of worst and other forms of labor in the agreement and used these distinctions to show that at least some forms of the labor alleged in the complaint would be prohibited by the treaty. ${ }^{118}$ The court went on to discuss the lack of bright-lines in child labor and how this treaty articulated the few lines that did exist. 119

Convention 182 has been successful in reaching an international consensus, with 171 countries ratifying it. However, this consensus came at a cost; the scope of the agreement is much narrower than Convention 138.120 The United States ratified the treaty with the understanding that it was not self-executing and would not be enforceable as a matter of U.S. law in U.S. courts. ${ }^{121}$ Liberia also ratified Convention 182.122 Article 3d of Convention 182 states that forms of labor that are considered the "worst" are those that harm "the health, safety, or morals of children." 123 Article 4 provides that whether work falls under Article 3d (that which is considered the "worst" forms) "shall be determined by national law or regulations... after consultation with the organizations of employers and workers concerned."124 Thus, Convention 182 places the duty to regulate child labor on states, with member states submitting annual reports on how

116. Roe v. Bridgestone Corp., 492 F. Supp. 2d 988, 1021 (S.D. Ind. 2007).

117. Convention on Worst Forms of Child Labour, supra note 6.

118. Bridgestone Corp., 492 F. Supp. 2d at 1021-22.

119. Id. at 1022.

120. See generally Dennis, supra note 109 (discussing the negotiations surrounding Convention 182 and what is meant by the terms hazardous work and education in the agreement).

121. See International Labour Organization, Convention Concerning the Prohibition and Immediate Action for the Elimination of the Worst Forms of Child Labor, Report of the Tripartite Advisory Panel on International Labor Standards to the President's Committee on the International Labor Organization Regarding Convention No. 182 On the Worst Forms of Child Labor, adopted July 28, 1999, 1999 WL 33292717.

122. Liberia, ILOLEX: DATABASE OF INT'L LABOUR STANDARDS, http://www.ilo.org/iloled/ cgi-lex/ratifce.pl?Liberia (last visited Sept. 30, 2010).

123. Convention on Worst Forms of Child Labour, supra note 6.

124. Id. at art. 4. 
they are implementing the conventions. ${ }^{125}$

Though each of these agreements individually might not provide enough evidence of an international norm to allow for jurisdiction of a private cause of action under Sosa, the widespread signing and ratification of the three agreements together might. All three of the conventions prohibit at least some forms of child labor, and all prohibit "forced and hazardous" labor, such as the plaintiffs allege in their complaint. Despite the cultural, social, and political difficulties in determining exactly what child labor practices should be allowed on an international level, on a domestic level, a U.S. court following the standards articulated in Sosa can examine evidence of a prohibition on "forced and hazardous" child labor based on international norms, and this is precisely what the court did in Flomo. Thus, the forces of globalization may be able to have more of an impact on child labor practices through domestic courts, at least in the United States, than through international agreements by themselves.

\section{B. The Constraints of ATS Child Labor Litigation}

After the Flomo court found that the plaintiffs' child labor claims had passed the jurisdictional bar of Sosa and properly alleged a violation of an international norm, the plaintiffs began discovery. As one of the Flomo plaintiffs' attorneys noted in an interview, the Flomo litigation was "very complex in terms of the amount of documents, the amount of witnesses, [and] the number of expert witnesses" when compared to other forms of employment litigation. ${ }^{126}$ Overall, ATS litigation "takes longer and is more expensive"; it is "employment law on a global scale." 127 For example, because the attorneys are so distant from their clients, even with local counsel in Liberia, it can take a

125. International Labour Organization Constitution art. 22, June 28, 1919, 49 Stat. 2712, 15 U.N.T.S. 35. Nations or individuals may file complaints with the ILO if they are dissatisfied with a nation's compliance with the convention. A nation may refer the complaint to the International Court of Justice (ICJ) for a binding determination on whether a nation's laws are sufficient under a treaty. Id. at arts. 24-31.

126. The plaintiffs' attorney that was interviewed has been to Liberia four times in relation to the case, each time staying for multiple weeks. Email Interview with Kimberly Jeselskis, Attorney, Jeselskis Law Office (July 27, 2010).

127. As the litigation was on a global scale, various global actors were involved. At least one NGO provided support, and the plaintiffs relied on such documents as the Save My Future Foundation (SAMFU) report and U.N. reports. The Liberian government did not assist the Plaintiffs in their litigation efforts at all, as its relationship with Firestone is very sensitive. Further, there was surprisingly little media involvement other than the initial media attention when the case was first filed. Id. 
substantial amount of time to coordinate something as simple as having a witness sign a declaration. ${ }^{128}$

Use of the ATS as a governance tool is not without repercussions. Various arguments made in the Flomo case indicate that the plaintiffs and their attorneys are not always certain that the consequences of the suit are worth it. In addition to being limited by the logistical realities of litigating claims from a developing state such as Liberia, the plaintiffs in Flomo and their attorneys had to be vigilant in protecting witnesses for their case and in ensuring the continued employment of the plaintiffs' guardians. 'Throughout the litigation, the plaintiffs' guardians' continued employment on the plantation was in jeopardy. The plaintiffs' attorneys acted as funambulists in crafting their arguments to lessen the risk to the plaintiffs' and their guardians. Though they sought to end the "worst forms of child labor," that very labor continued to be available to the adults on the plantation. ${ }^{129}$ Only fifteen percent of all Liberians are employed in the formal sector, ${ }^{130}$ and work as a tapper on the Firestone plantation is often the only means of survival. ${ }^{131}$ Firestone Liberia also provides schooling, housing, health services for its employers and their families, and services that may be

128. Id.

129. Another issue was whether the plaintiffs should be allowed an interpreter. After a particularly long deposition of one of the child plaintiffs, in which the plaintiff stated that she did not understand the question 112 times, plaintiffs' counsel filed a protective order for use of an interpreter for future depositions. Transcript of Telephone Conference at 9 10, Flomo, No. 06-cv-00627 (No. 125). An interpreter is warranted pursuant to 28 U.S.C. $\$$ 1827(d) when a party "speaks only or primarily a language other than the English language ... . so as to inhibit such party's comprehension." The dispute that arose between the parties was whether Liberian English was different from American English. The plaintiffs presented declarations from multiple experts stating that Liberian English was a distinct language. Defendants argued that any misunderstandings that occurred between Liberian English and American English could be resolved without the aid of a translator. After a telephone hearing, the court granted plaintiff's motion to use interpreters in future depositions. Transcript of Telephone Conference, supra, at 5-32. See generally Plaintiff' Motion and Memorandum in Support of Motion For a Protective Order to Require Defendants to Conduct the Depositions of Plaintiffs and Their Third-Party Liberian Witnesses with Interpreters, Flomo, No. 06-cv-00627 (No. 109) (arguing that Liberian English differs from American English, and explaining arguments why plaintiffs need a protective order). In future labor cases, whether an interpreter is needed should be considered, even in the case where a non-American form of English is used.

130. Bureau of African Affairs, Background Note: Liberia, U.S. DEPARTMENT OF STATE, (Aug. 17, 2010), http://www.state.gov/r/pa/ei/bgn/6618.htm.

131. See United NAtions Liberia, United Nations Development assistance Framework Liberia 2008-2012: CONSOLIDATING PEACE AND NATIONAL RECOVERY FOR SUSTAINABlE DEVEloPMENT 11, 16 (2008), available at http://unliberia.org/doc/undaf doc.pdf (noting that fifty-one percent of all Liberians are food insecure or are highly vulnerable to food insecurity and that only forty-one percent of all Liberians have any health coverage). 
unattainable outside of the plantation. ${ }^{132}$ Because the plaintiffs were extraterritorially located, laws that protect individuals from retribution for either bringing suit over labor violations or testifying in such a suit do not always apply, though some do exist. ${ }^{133}$ The steps taken to preserve the employment of adults involved in the Flomo case is discussed below, as well as the problems that inevitably arise when trying to protect the employment of adults involved in the very labor that the plaintiffs are simultaneously arguing against.

\section{Preservation of Plaintiffs' Guardians Employment by Protecting Their Identities}

When first filing the complaint, the plaintiffs used pseudonyms to protect the children's identities. This was necessary, according to the plaintiffs, "due to fear of retaliation against themselves and their families by persons who are employees and/or agents of the Defendants." 134 The complaint noted there would be:

significant pressure on local Firestone employees and managers to identify and silence the Plaintiffs for daring to speak out about the generations of suffering that have gone on at the Firestone Plantation. . . . [Additionally,] the Plaintiffs, if identified by name, would face termination, and they would be kicked out of their Firestone-provided shack, leaving them homeless and destitute. They would have no legal recourse in Liberia for this retaliation. ${ }^{135}$

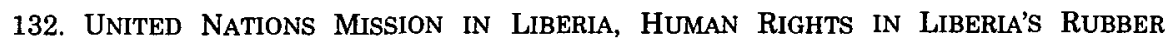
PLANTATIONS: TAPPING INTO THE FUTURE 28, 39-41, 44, 51 (May 2006), available at http://unmil.org/documents/human_rights_liberiarubber.pdf; Plaintiffs' Motion for Protective Order and, or in the Alternative, Motion for Preliminary Injunction at 2-3, Flomo, No. 06-cv-00627 (No. 246) [hereinafter Plaintiffs' Motion for Protective Order] (arguing that terminating plaintiffs' guardians "will not only take away the paltry wage that they are earning, but will effectively put them out on the streets as their terminations will prompt Firestone to evict them from their company housing').

133. See 18 U.S.C. $\$ 1512$ (2010) (prohibiting any person from intimidating, threatening, or corruptly persuading another person with the intent to cause that person to "withhold testimony, or withhold a record, document, or other object, from an official proceeding," $\S$ 1512(b)(2)(A), and providing for extraterritorial jurisdiction, $\S 1512(\mathrm{~h})$ ); 28 U.S.C. $\$ 1651$ (permitting courts to "issue all writs necessary or appropriate in aid of their respective jurisdictions and agreeable to the usages or principles of law").
}

134. Complaint, supra note 11 , at para. 8.

135. Id. 
However, as the litigation proceeded and the plaintiffs were deposed, the plaintiffs' names slowly became known to the defendants, and, in April 2009, their full names were revealed by court order. ${ }^{136}$

The plaintiffs also took steps to protect any witnesses who were assisting them with their case by discussing what they knew about the child labor policies on the plantation. Soon after the suit was filed, Firestone Liberia implemented a "zero-tolerance policy" against employees involving children in their work and stated that anyone who violated it would "risk losing their job." ${ }^{137}$ In order for the plaintiffs to discover whether child labor was continuing despite the policy, they needed to ask witnesses about the practices. However, Firestone threatened to fire the children's guardians if the children testified that they were working. ${ }^{138}$ The plaintiffs were also concerned about selective enforcement of the zero-tolerance policy against those individuals that helped plaintiffs with their case. ${ }^{139}$

In order to deal with this concern, the plaintiffs sought a preliminary injunction ensuring that Firestone Liberia could not retaliate against the plaintiffs' witnesses that testified about whether children were currently working or had worked on the Liberian plantation. ${ }^{140}$ The court did not grant the injunction, but did prevent the defendants from receiving the plaintiff's responses to interrogatories by sealing the responses until after the court ruled on the motion for summary judgment. ${ }^{141}$ The court later reconsidered its motion and ordered the interrogatory responses to be unsealed. ${ }^{142}$ At that time, the court noted its concern "that continuing to allow [the] Plaintiffs to avoid complying with their discovery obligations perpetuates the very practices [the] Plaintiffs contend to be illegal and universally

136. Order, Flomo, No. 06-cv-00627 (No. 194); Notice of Caption Change, supra note 8.

137. About Firestone Liberia, BRIDGESTONE AMERICAS, INC., http://www.bridgestonefirestone.com/about_bg_index.asp?id=about/fslbg (last visited Sept. 30, 2010) (discussing briefly the zero-tolerance policy on child labor). The effectiveness of the recently implemented zero-tolerance policy was in dispute: Plaintiffs stated that Firestone only made "superficial cosmetic attempts to enforce a prohibition of child labor at times of key significance in this case. . . [H]eadmen, overseers, and superintendents tell the children to hide when they see cars coming and then to resume their normal work." The rest of the time "business as usual continued" with "children performing hazardous work with Firestone's knowledge and encouragement." See Plaintiffs' Motion for Protective Order, supra note 129 , at 3 .

138. Plaintiffs' Motion for Protective Order, supra note 129, at 3.

139. Id.

140. Id. at 1.

141. Entry on Motion for Protective Order and, or in the Alternative, Motion for Preliminary Injunction at 6, Flomo, No. 06-cv-00627 (No. 352) [hereinafter Entry on Motion for Protective Order].

142. Order at 4-6, Flomo, No. 06-cv-00627 (No. 569). 
condemned 'worst forms' of child labor."143

The court's concern was logically valid. The plaintiffs, in effect, wanted to ensure that the "worst forms of child labor" were no longer occurring on the Firestone Plantation, but did not want the "zerotolerance" policy against child labor to be enforced against them and their guardians. In deciding not to grant the preliminary injunction, the court aptly stated:

that regardless of the Defendants' motives, enforcing the policy as to the Plaintiffs, even if that enforcement is selective, will achieve what is ostensibly the core goal of this litigation-protecting the Plaintiffs from the dangers of the worst forms of child labor. . . . The Court recognizes that . . . it will also likely subject the Plaintiffs to dangers of another sort-the very real peril of being homeless and destitute in Liberia. Perhaps performing child labor is the lesser of two evils, perhaps it is not; that is a decision for the individual Plaintiffs to make. ${ }^{144}$

The plaintiffs, in continuing the ATS child labor litigation, had to determine the lesser of the two evils and understand how being a plaintiff in such a case could affect their very ability to survive.

\section{The Limits of Relief Under the ATS}

In their claims for injunctive relief, plaintiffs did not just ask for the "worst forms of child labor" to cease on the Liberian rubber plantation, but also requested a "reduction in task sizes attendant duties associated with tapping so one adult person can complete the daily production quotas without the assistance of children or additional adults." 145 This form of relief was requested to ensure that the adult laborers would no longer need to use child labor to complete their tasks. The court denied

143. Id. at 5-6.

144. Entry on Motion for Protective Order, supra note 141, at 5.

145. Exhibit A to Defendants' Motion for Summary Judgment on Plaintiffs' Claim for Injunctive Relief and to Strike the Prayer for Injunctive Relief at 4, Flomo, No. 06-cv00627 (No. 490-1) (citing from Plaintiffs Statement of Damages). Though the plaintiffs originally sought injunctive relief, the plaintiffs decided not to oppose the defendants' summary judgment motion to rule on claims of injunctive relief. The court granted the defendants' summary judgment motion as to injunctive relief. Thus, the plaintiffs now are suing solely for compensatory and punitive damages. Order at 1, Flomo, No. 06-cv-00627 (No. 566). 
the injunction and noted, "it does not appear ... that it has the power to give the Plaintiffs the remedy they really want: a reduction of quotas to eliminate the alleged need for parents to enlist their children to help them."146 Though the ATS can be a tool to eliminate the "worst forms of child labor," it "does not provide a warrant to oversee labor practices all over the world, and it does not mean that the court must open its doors to address the plights of thousands of people who will never come anywhere near the United States."147 Liberia remains very different than the United States and, as discussed above, child labor may be the only way for children on rubber plantations to survive. Thus, future parties must carefully consider the consequences in bringing suit for violations of international norms and whether the risk they are undertaking is worth the changes an ATS suit may bring.

\section{CONCLUSION}

As the global marketplace continues to expand, multinational corporations continue to seek the cheapest form of labor to remain competitive. The ATS, however, provides a limited regulatory tool for ensuring that corporations do not engage in the "worst forms of child labor." In this way, U.S. courts are able to influence global labor practices. This may slowly pressure multinational corporations and, in turn, nation-states to change their labor practices to ensure they do not violate international norms, influencing the practices of the global marketplace through domestic measures (i.e. from the bottom-up). Since the Supreme Court's ruling in Sosa, the lower courts have affirmation that using the ATS as a means of redress for violations of international norms is proper, as long as the courts proceed with caution.

Based on the relevant international agreements, the Flomo plaintiffs' claim that the "worst forms of child labor" constitute a violation of international norms is sufficient for recognition under the ATS and the law of nations. Yet, future plaintiffs must be diligent to ensure that the employment of parties not engaged in the "worst forms of child labor" is maintained, which may lead to difficulties throughout the litigation. In the end, though judgment was rendered in favor of defendants, it is important to remember the children and ensure that they are not exploited by, at the very least, U.S. corporations. The repercussions of allowing children to perform forced and hazardous labor will not only limit their future, but will negatively affect the core infrastructures of developing countries.

146. Entry on Motion for Protective Order, supra note 141, at 4.

147. Roe v. Bridgestone Corp., 257 F.R.D. 159, 173 (S.D. Ind. 2009). 
